\title{
PENINGKATAN KEAKTIFAN DAN PRESTASI BELAJAR SISWA SMP PGRI SENGON DALAM PEMBELAJARAN FISIKA MENGGUNAKAN METODE POE
}

\author{
Amri Baihaqi Mashuda \\ Program Studi Fisika, Universitas Gajayana Malang \\ Email: amribaihaqimsi@gmail.com \\ DOI: http://dx.doi.org/10.29303/jpft.v5i1.1058
}

\begin{abstract}
$\overline{\text { Abstract - In the modern era, physics lessons are still one of the subjects that some students find }}$ difficult.When students feel difficult to learn, the result is a decrease in the value of physics lessons. Based on these problems, researchers try to provide solutions to overcome the difficulties students in learning physics. This research was conducted at the PGRI First Middle School in Sengon Village, Purwosari District.Improving student learning achievement can be influenced by several factors, one of which is the activity of students in the learning process of physics. On increasing learning activity students can use several methods, one of which is the POE method (Prediction, Observation, and Explanation). Measuring activity with observations made by peers in the learning process, while achievements with questions given in cycles I and II. Based on the results of the research cycle I and cycle II in terms of activity and student learning achievement said to increase well. On results of these research, it can be said that physics learning using the POE method is a solution to overcome a decline in student learning achievement.
\end{abstract}

Keywords: Physics Learning, POE Method

\section{PENDAHULUAN}

Pendidikan sekolah menengah pertama merupakan dasar siswa dalam memperoleh ilmu pengetahuan untuk melanjutkan ke pendidikan selanjutnya. Pada dasarnya sistem pendidikan nasional merupakan upaya bangsa dalam membangun keberlanjutan warisan budaya (Musanna, (2017). Fisika merupakan bagian dari sains (IPA) di mata pelajaran pendidikan sekolah menengah (Rahmatullah et al. (2017).

Tujuan pembelajaran merupakan prestasi belajar (Adib \& Santoso, 2016). Mengenai masalah prestasi belajar, pencapaian nilai matematika dan fisika siswa Indonesia di dunia Internasional sangat rendah (Rosida \& Suprihatin, 2019). Salah satu permasalahan yang muncul dari penyelenggaraan pendidikan salah satunya, yaitu penurunan prestasi belajar siswa. Faktor internal merupakan salah satu yang mempengaruhi prestasi belajar siswa, seperti: intelegensi, bakat, minat, kelelahan, dan cara belajar) (Aini \& Sudira, 2015). Faktor lain yang mempengaruhi, yaitu proses belajar mengajar (Sahidu, et al (2018). Cara belajar siswa dalam kelas merupakan salah satu faktor yang mempengaruhi penurunan prestasi belajar siswa SMP PGRI Sengon, sehingga perlunya strategi dalam proses pembelajaran. Proses pembelajaran selama ini di dominasi guru atau biasa disebut Teacher Center (Wahyuni R et al. (2016). Empat pengaruh hasil belajar peserta didik, seperti : media pembelajaran, gaya praktik belajar, sarana, dan strategi pembelajaran (Ernita, et al. (2016). Dalam arti sempit strategi pembalajaran merupakan sama sama, sedangkan dalam arti luas cara untuk mencapai tujuan (Nasution, (2016). Dengan strategi pembelajaran diharapkan menjadi solusi untuk mengatasi siswa SMP PGRI yang kurang aktif dalam pembelajaran.

Dengan pembelajaran aktif, siswa dituntut untuk melakukan ekperimen secara langsung dalam proses pembelajaran. Peningkatan aktivitas siswa dapat berpengaruh terhadap peningkatan hasil belajar siswa (Winarti, (2013). Pembelajaran aktif mampu memfasilitasi 
life skill, sehingga siswa tidak hanya mempunyai keterampilan kognitif tapi juga mampu mengamati lingkungan sekitar (Kumara, (2004). Model pembelajaran POE merupakan model pembelajaran yang sebagian besar proses pembelajarannya berpusat pada siswa. Ini dibuktikan dengan fase prediction dimana siswa disini dituntut untuk memprediksi dan berfikir apa yang dilakukan oleh guru dan pada fase observastion, siswa dituntut untuk bisa mengobservasi atau mengeksperimenkan apa yang menjadi perintah dari guru yang bersangkutan. Peningkatan mutu dalam pendidikan sains atau fisika yang mengacu pada kurikulum 2013 menerapkan pembelajaran yang menitikberatkan pada keterampilan tertentu, salah satunya keterampilan dalam bereksperimen (Wahyuni et al. (2015). Eksperimen dapat membuat siswa lebih percaya atas kebenaran atau kesimpulan berdasarkan percobaannya, sehingga dapat memungkinkan siswa belajar secara aktif dan mandiri (Oviana \& Maulidar, (2013). Disini sangat dituntut keaktifan seorang siswa dalam menjalankan eksperimen, kemudian fase explanation siswa dituntut mengkomunikasikan dalam bentuk kalimat tentang apa yang sudah di obeservasi atau di eksperimenkan.

Dalam proses pembelajaran fisika diketahui bahwa siswa kurang aktif sehingga pemahaman siswa rendah, akibatnya prestasi siswa SMP PGRI Sengon menurun. Hasil observasi lain di SMP PGRI Sengon, siswa apabila diajak melakukan eksperimen membuat siswa lebih senang dan lebih bersemangat dalam mengikuti pembelajaran fisika. Dengan hasil observasi inilah peneliti mencoba menerapkan model pembelajaran POE karena sesuai dengan karakteristik siswa di SMP PGRI Sengon. Dengan demikian penerapan model pembelajaran POE diharapkan bisa meningkatkan keaktifan dan prestasi belajar siswa SMP PGRI Sengon.

\section{METODE PENELITIAN}

\section{Paparan data pra - tindakan}

Dalam penelitian ini peneliti bertindak sebagai pelaksana penelitian, pada tanggal 22 - 25 Desember 2013 melakukan studi pendahuluan terhadap siswa SMP PGRI Sengon dengan cara mengikuti proses pembelajaran di dalam kelas dari awal sampai akhir pelajaran. Berdasarkan hasil studi pendahuluan diperoleh bahwa metode yang dipakai di dalam kelas adalah ceramah dan pemberian tugas, pernah sesekali dilakukan diskusi. Guru mengawalinya dengan pembukaan kemudian dilanjutkan dengan penjelasan materi. Siswa cenderung kurang bersemangat dengan metode pembelajaran tersebut.

Pada tanggal 14 Desember 2013 peneliti melakukan koordinasi dengan guru fisika, diperoleh kesepakatan pelaksanaan penelitian dilaksanakan mulai tanggal 16 Desember 2013. Standar ketuntasan belajar minimal siswa SMP PGRI Sengon yang ditentukan oleh pihak sekolah yaitu sebesar 70. Nilai prestasi dari 26 siswa yang diatas standar ketuntasan belajar sebanyak 13 siswa, sedangkan siswa yang dibawah sebanyak 13 siswa dengan nilai rata-rata 69,5. Jadi dapat disimpulkan bahwa persentase siswa yang lulus sekitar 50\%.

\section{Paparan Data Tindakan}

Pelaksanaan tindakan meliputi tahap merencanakan (plan), melaksanakan (action), mengamati (observe) dan merefleksi (reflect). Pada tahap ekperimen, pelaksanaan tindakan adalah pelaksanaan kegiatan pembelajaran yang meliputi siklus tindakan I dan siklus tindakan II 
Refleksi Data Penelitian Siklus I dan II

Pada kegiatan penelitian ini perlu dilakukan refleksi untuk mengetahui perbandingan keberhasilan kegiatan pembelajaran pada siklus I dan siklus II (lihat tabel 1 dan 2).

Tabel 1. Refleksi 1

\begin{tabular}{|c|c|c|}
\hline Indikator & Kelemahan Siklus I & Perbaikan \\
\hline $\begin{array}{l}\text { Keterlaksanaan } \\
\text { Pembelajaran }\end{array}$ & $\begin{array}{l}\text { Tahap penutup, } 2 \text { komponen } \\
\text { tidak dilaksanakan }\end{array}$ & $\begin{array}{l}\text { Diharapkan semua } \\
\text { komponen dapat } \\
\text { terlaksana }\end{array}$ \\
\hline Keaktifan Siswa & $\begin{array}{llr}\text { Indikator } & \text { oral } & \text { activities } \\
\text { dinyatakan } & \text { sangat rendah, } \\
\text { dikarenakan } & \text { tidak terlaksana } \\
\text { sama sekali } & & \end{array}$ & $\begin{array}{l}\text { Diharapkan semua } \\
\text { komponen dapat } \\
\text { terlaksana }\end{array}$ \\
\hline
\end{tabular}

Tabel 2. Refleksi 2

\begin{tabular}{|c|c|c|}
\hline Indikator & Kelemahan Siklus I & Perbaikan \\
\hline $\begin{array}{l}\text { Keterlaksanaan } \\
\text { Pembelajaran }\end{array}$ & $\begin{array}{l}\text { Tahap penutup, } 1 \text { komponen } \\
\text { tidak dilaksanakan }\end{array}$ & $\begin{array}{l}\text { Bagi peneliti atau para } \\
\text { guru diharapkan semua } \\
\text { komponen dapat } \\
\text { terlaksana }\end{array}$ \\
\hline Keaktifan Siswa & $\begin{array}{l}\text { Indikator oral activities terjadi } \\
\text { peningkatan }\end{array}$ & $\begin{array}{l}\text { Bagi peneliti atau para } \\
\text { guru diharapkan semua } \\
\text { komponen dapat } \\
\text { terlaksana }\end{array}$ \\
\hline
\end{tabular}

\section{HASIL DAN PEMBAHASAN}

Hasil penelitian menunjukkan peningkatan yang signifikan dari siklus I dan II dalam keterlaksanaan pembelajaran. Berdasarkan tabel 3, peningkatan siklus I ke siklus II sebesar 8,33 \%. Data ini menunjukkan bahwa ketertarikan siswa SMP PGRI Sengon dalam pembelajaran fisika sudah mulai muncul, ini merupakan keberhasilan dalam metode POE yakni tahap prediksi.

Tabel 3. Keterlaksanaan Pembelajaran

\begin{tabular}{lcccc}
\hline \multicolumn{1}{c}{ Indikator } & Siklus I & Siklus II & Keterangan & Persentase \\
& & & & \\
\hline Membuka Pelajaran & $75 \%$ & $75 \%$ & Konstan & $0 \%$ \\
Kegiatan Inti & $100 \%$ & $100 \%$ & Konstan & $0 \%$ \\
Kegiatan Penutup & $50 \%$ & $75 \%$ & Meningkat & $25 \%$ \\
Rata-Rata & $75 \%$ & $83,33 \%$ & Meningkat & $8,33 \%$ \\
\hline
\end{tabular}

Tahap observasi atau ekperimen siswa dituntut aktif dalam proses pembelajaran dalam kelas. Dengan melihat tabel 4, menunjukkan bahwa rata-rata keaktifan belajar siswa dari siklus I ke siklus II meningkat sebesar 3,41\%. Dengan hasil ini membuktikan bahwa metode POE cocok untuk karakteristik siswa, selain merupakan keberhasilan tahap observasi atau eksperimen dalam metode tersebut. 
Tabel 4. Keaktifan Siswa

\begin{tabular}{lcccc}
\hline \multicolumn{1}{c}{ Indikator } & Siklus I & Siklus II & Keterangan & Persentase \\
\hline Visual Activities & $100 \%$ & $83,33 \%$ & Menurun & $16,67 \%$ \\
Oral Activities & $50 \%$ & $55 \%$ & Meningkat & $5 \%$ \\
Listening & $100 \%$ & $83,33 \%$ & Menurun & $16,67 \%$ \\
Activities & & & & \\
Writing Activities & $100 \%$ & $83,33 \%$ & Menurun & $16,67 \%$ \\
Motor Activities & $100 \%$ & $100 \%$ & Konstan & $0 \%$ \\
Mental Activities & & $50 \%$ & Meningkat & $50 \%$ \\
Emotional & $69,04 \%$ & $54,74 \%$ & Menurun & $14,3 \%$ \\
Activities & & & & \\
Rata-rata & $74,15 \%$ & $77,56 \%$ & Meningkat & $3,41 \%$ \\
\hline
\end{tabular}

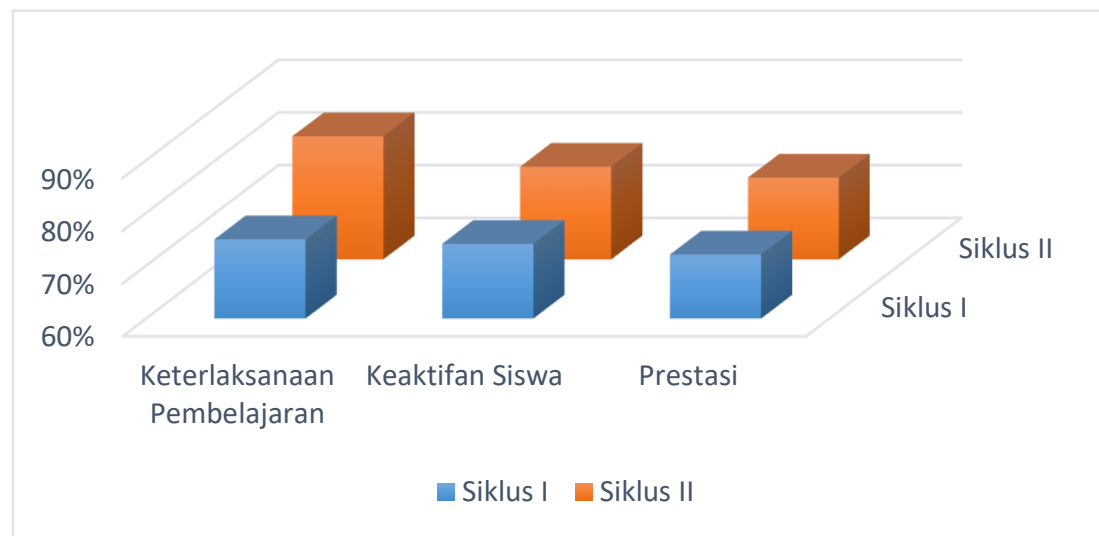

Gambar 1. Grafik peningkatan prestasi belajar

Ketika keaktifan siswa sudah meningkat, maka artinya siswa sudah mulai memahami pelajaran fisika. Dengan pemahaman yang dimiliki siswa, melihat gambar 1 prestasi belajar siswa meningkat seiring meningkatnya keberhasilan tahap prediksi dan tahap observasi. Ringkasnya prestasi belajar siswa meningkat seiring meningkatnya keterlaksanaan dan keaktifan siswa SMP PGRI Sengon pada siklus I dan siklus II.

\section{PENUTUP}

Berdasarkan data penelitian siklus I dan siklus II, prestasi belajar siswa SMP PGRI Sengon meningkat dengan baik. Dengan demikian metode POE telah berhasil digunakan dalam meningkatkan keaktifan siswa yang berdampak peningkatan prestasi belajar siswa.

\section{REFERENSI}

Adib F \& Santoso B. (2016). Upaya Peningkatan Prestasi Belajar Siswa dengan Disiplin Kerja Guru. Jurnal Pendidikan Manajemen Perkantoran. 1(1); 209-214.

Aini S N, \& Sudira P. (2015). Pengaruh Strategi Pembelajaran, Gaya Belajar, Sarana Praktik, dan Media terhadap Hasil Belajar Patiseri SMK Se-Gerbang kertasusila. Jurnal Pendidikan Vokasi. 5(1); 88-102.

Ernita, Tiara, \& Rabiatul A T. (2016). Hubungan Cara Belajar dengan Prestasi Belajar Siswa dalam Mata Pelajaran PKn pada Siswa Kelas X SMA Negeri 1 Banjarmasin. Jurnal Pendidikan Kewarganegaraan. (6)11 ; 971-979.

Kumara A. (2004). Model pembelajaran "Active Learning" mata pelajaran sains tingkat SD Kota Yogyakarta sebagai upaya peningkatan "Life Skills". Jurnal psikologi. 31(2) ; 63-91. 
Musanna A. (2017). INDIGENISASI PENDIDIKAN: Rasionalitas Revitalisasi Praksis Pendidikan Ki Hadjar Dewantara. Jurnal Pendidikan dan Kebudayaan. 2(1): 117-133.

Nasution M.I.P. (2016). Strategi pembelajaran efektif berbasis mobile learning pada sekolah dasar. IQRA': Jurnal Perpustakaan dan Informasi. 10: (1):1-14.

Oviana W, \& Maulidar. (2013). Penggunaan Metode Eksperimen Pada Pembelajaran Materi Sifat Bahan Dan Kegunaannya Terhadap Hasil Dan Respon Belajar Siswa Kelas IV Min Tungkob Aceh Besar. Jurnal Ilmiah Didaktika. 13 (2): 336-350.

Rahmatullah, Sahidu H, \& Syahrial A. (2017). Pengaruh Model Pembelajaran Kooperatif Tipe Group Investigation (GI) dengan Teknik Open-Ended Problem terhadap Aktifitas dan Hasil Belajar Fisika Siswa SMAN 3 Mataram. Jurnal Pendidikan Fisika dan Teknologi. 3 (2): 109-118.

Rosida P, \& Suprihatin, T. (2019). Pengaruh pembelajaran aktif dalam meningkatkan prestasi belajar Fisika pada siswa kelas 2 SMU. Jurnal Proyeksi. 6 (2): 89-102.

Sahidu H, Gunawan, Rokhmat J, \& Rahayu S. (2018). Pengembangan Perangkat Pembelajaran Fisika Berorientasi pada Kreativitas Calon Guru. Jurnal Pendidikan Fisika dan Teknologi. Volume 4 (1): 1-6.

Wahyuni D.T, Bektiarso S, \& Wahyuni S. (2015). Penerapan Strategi Pembelajaran Aktif Tipe Prediction Guide Dalam Pembelajaran Fisika Di SMA. JURNAL PEMBELAJARAN FISIKA. 4 (1): 38 - 43.

Wahyuni R, Hikmawati, \& Taufik M. (2016). Pengaruh Model Pembelajaran Inkuiri Terbimbing dengan Metode Eksperimen terhadap Hasil Belajar Fisika Siswa Kelas XI IPA SMAN 2 Mataram Tahun Pelajaran 2016/2017. Jurnal Pendidikan Fisika dan Teknologi. 2 (4): 164-169.
Winarti. (2013). Peningkatan Keaktifan Dan Hasil Belajar Siswa Pokok Bahasan Penyusutan Aktiva Tetap Dengan Metode Menjodohkan Kotak. Dinamika Pendidikan. 8 (2):123 - 132. 